\title{
PERSONAL PERSPECTIVES THAT MATTER
}

\author{
Stephanie Kamai \\ Education Divsion, University of Hawai 'i, West O'ahu (USA)
}

\begin{abstract}
The purpose of this paper is to contribute to the existing literature about the theoretical and practical aspects of lesson study and its usefulness in preservice teacher reflectivity. Lesson study is a professional development model that began in Japan and is used in schools and universities among educators in many different parts of the world. Collaborative research lesson study, a variation of lesson study that maintains essential elements of lesson study used in Japan, has been used with preservice teachers at a small university in Hawai' $i$. This paper seeks to highlight the differences and suggests areas of study for further consideration.
\end{abstract}

Keywords: Lesson study, collaboration, groupwork, inquiry, reflection.

\section{Introduction}

There are five steps in lesson study: goal-setting, lesson planning, research lesson, post-lesson discussion and reflection (Fujii, 2016). On the surface these steps appear easy to follow. After experimenting with lesson study for four years, it is clear that our program uses some essential components of lesson study but is restrained due to the limitations inherent to teacher preparation for undergraduate students. Preservice teachers have limited teaching experience, authority and influence in a school. CRLS is not done school wide. CRLS is carried out one preservice teacher at a time in one classroom. The focus for our program is to provide preservice teachers with an experience that will reinforce collaboration, inquiry, and reflection through Collaborative Research Lesson Study (CRLS). Lesson study begins with a research question that is the result of careful consideration regarding student performance.

\section{Lesson study theory in practice}

The CRLS process begins with creating groups of similar grade level considerations and common field placement assignments. The groups meet on the first day of the semester and establish norms for groupwork (Cohen \& Lotan, 2014) and discuss what they have learned about their school community, the students in their classrooms, and a learning challenge they have learned about from their mentor teacher or observations they have made. Mentor teachers may have already provided suggestions for an instructional or pedagogical strategy the school plans to use to address the learning challenge. Groups who stay in dialogue (Patterson, K., Grenny, J., McMillan, R., \& Switzler, A., 2002) experience success in moving to the next step and begin to form communities of practice which becomes the process that gives the group an identity (Wenger, 1998).

A key component during this phase of lesson study is for preservice teachers to anchor their ideas and wonderings with a research question [Fujii, 2016]. This phase is messy and can be frustrating. They are working on several tasks at the same time. They might be researching the learning challenge itself, school curriculum, and/or pedagogical and instructional strategies without having a clear theme or focus. Conceptualizing the research question can be a daunting task but a crucial step that informs their progress. If the research question is written without fully understanding the discussions, the groups will go off course.

Eventually, preservice teachers agree on a lesson to teach to a group of students in one of their classrooms. One preservice teacher agrees to teach the lesson while the other group members observe. Observers agree to take notes on predetermined areas that they believe will provide rich data. The mentor teacher and content specialist is invited. The primary purpose of observing practice in lesson study is to fine-tune instructional improvements and assess progress on how classroom students are responding to 
the lesson. Observations focus on collecting evidence related to what teaching and learning looks like when the action plan is implemented. A question I ask preservice teachers to think about when finalizing the lesson plan before teaching the lesson is: Based on what you know about your students, what misconceptions might they have? This question typically generates a change to the lesson and alternative ideas to use if the situation arises during the actual lesson. I encourage preservice teachers to think on their feet, this preparation helps them to feel more confident.

Noteworthy to the CRLS process is a post lesson debrief session. This process typically takes 2-4 hours and focuses on the students, not the teacher. What were students saying? What questions did student ask? How do we know students were engaged? What were students doing when they were not participating? Debriefing the session in this way encourages preservice teachers to naturally reflect on what the teacher was doing at the time while focusing on students. The group then evaluates student work and makes some interpretations about the results. Preservice teachers are asked to provide a rationale for the changes they would make the next time they teach the lesson.

A final group paper that documents the entire project throughout the semester is submitted. Students summarize their lesson study project and share the results at a public presentation at the end of the semester. The lesson study paper documents the lesson project that students grapple with during the semester. It is a messy and ambiguous endeavor that captures the complex nature of the teaching process. For many students the demand can be daunting. The public presentation, pre COVID, was held in a local school. Some principals offered professional development credit for teachers who attended the lesson study presentation. Student presentations reflected the arduous task of writing the paper. After working on the paper for several weeks, they were ready to present what they did, smoothly.

Finally, preservice teachers submit a Personal Perspectives narrative at the end of the semester. The general prompt asks them to reflect on the lesson study process. The perspectives of preservice teachers who participated in those in-between spaces (Hyatt, 2015) during the lesson study process are intended to shed light on the areas of lesson study that are meaningful to them and the value of the student teaching experience. Their perspectives are

\section{Lesson study as a reflective activity}

Student teachers complete a personal reflection to a general prompt that asks them to reflect on the lesson study process. Myers conducted a study of preservice students and found that reflection is a complex skill and future teachers should be taught how to reflect before actually beginning the lesson study process (2012). Chassels \& Melville posit that the lesson study has benefits and challenges for inservice and preservice professional development. The authors state that, "The benefits include the development of teacher candidates' new insights into the needs of students, an increased awareness of different teaching strategies, and the importance of collaboration. The challenges are mainly focused on the issue of time and school administrative structures that impede teacher collaboration" (2009).

Lesson study or Jugyou kenkyuu originated in Japan but has been implemented and studied in the United States. The research on lesson study highlights the many systems in place where educators are trying out the lesson study professional development model (Lewis, Perry \& Murata, 2006). Teachers develop curriculum, write student learning objectives that align with state and national standards, assess student performance, and modify instruction and learning activities in order to accommodate each learner.

CLRS is quite different from lesson study in Japan. I argue that the structural components (Takahashi, A. \& Yoshida, 2004) adds value to our program and, perhaps in other parts of the world, (Doig, Be. \& Groves, S., 2011) needs reflection about ways in which CRLS can contribute to the existing research on its impact on preservice teachers.

\section{Conclusion}

When teaching professionals are focused on the strengths and possibilities that exist, and when they grapple through these tasks collaboratively and reflectively, an inside-out strategy occurs that honors the wisdom, experience, and sensitivity of classroom teachers (Jarvis, et.al, 2017). Lesson study is a valuable way for preservice teachers to gain authentic experiences with collecting data, setting goals and measuring student learning in preparation for the realities of their practice as beginning teachers. Lesson study is a process that honors teachers and the wisdom and instincts they individually and collectively bring to student learning while learning more about their craft.

A call for more research into what and how student teaching experiences contribute to preservice learning is needed. This paper presented a snapshot of the Collaborative Research Lesson Study used at one university. Research that will recount preservice teachers experiences about their engagement in the process, the problems and consequences that happen, as well as what is most significant to them is ongoing. 


\section{References}

Chassels, C. \& Melville, W. (2009). Collaborative, reflective, and iterative Japanese lesson study in an initial teacher education program: Benefits and challenges. Canadian Journal of Education, 32(4). 734-763.

Cohen, E.G. and Lotan, R. A. Designing Groupwork: Strategies for the Heterogeneous Classroom 3rd Edition, Teachers College Press; 3rd edition (2014). 256 pgs.

Doig, B and Groves, S. (2011). Japanese Lesson Study: Teacher Professional Development through Communities of Inquiry. Mathematics Teacher Education and Development, Vol. 13(1). 77-93.

Fujii, T. (2014). Implementing Japanese Lesson Study in Foreign Countries: Misconceptions Revealed. Mathematics Teacher Education and Development, 16(1).

Fujii, T. (2016). Designing and adapting tasks in lesson planning: a critical process of Lesson Study. ZDM Mathematics Education, Springer, 48. 411-423

Hammerness, K., Darling-Hammond, L., Bransford, J. et.al, (2005). How teachers learn and develop. In L. Darling-Hammond and J Bransford (Eds), Preparing Teachers for a Changing World: What Teachers Should Learn and Be Able to Do (358-389). San Francisco: Jossey-Bass.

Hyatt, J. (2015). Reflective Communities: Mentoring teacher candidates during the (in)between spaces of the practicum. Journal of Social Theory in Art Education, 35.

Jarvis, R., Dempsey, K., Gutierrez, G., Lewis, D., Rouleau, K., \& Stone, B. (2017). Peer coaching that works. McREL International. Denver: CO.

Lewis, C., Perry, R., \& Murata, A. (2006). How should research contribute to instructional improvement? The case of lesson study. Educational Researcher, 35(3), 3-14.

Myers, J. (2012). Lesson Study as a Means for Facilitating Preservice Teacher Reflectivity. International Journal for the Scholarship of Teaching and Learning, Vol. 6(1).

Patterson, K., Grenny, J., McMillan, R., \& Switzler, R. (2002) Crucial Conversations: Tools for Talking When Stakes are High. Mc-Graw Hill Contemporary. New York: New York.

Takahashi, A and Yoshida, M. (2004). Ideas for Establishing Lesson-Study Communities. Teaching Children Mathematics, 10(9).

Takahashi, A. and McDougal, T. (2016). Collaborative lesson research: maximizing the impact of lesson study. ZDM - Mathematics Education, Springer, 48. 513-526.

Wenger, E. (1998). Communities of practice: Learning, meaning, and identity. Cambridge: Cambridge University Press. 